\title{
Urgensi Perubahan Delik Biasa Menjadi Delik Aduan dan Relevansinya terhadap Perlindungan dan Penegakan Hak Cipta
}

\author{
Hanafi Amrani \\ Fakultas Hukum Universitas Islam Indonesia \\ h.amrani@uii.ac.id
}

\begin{abstract}
This article discusses two main issues: first, what is the urgency of the change in nature of offences from ordinary offence to be complaint offence in the copyright law; second, how is the relevance of the change in the nature of the offense to protect and enforce copyright. The urgency of changes in offenses is usually an offense against complaints because copyright is an exclusive right that is personal and civil rights. This personal and civil right indicate the absolute right of the creator or the copyright holder to the results of their work, including the right to report or not to infringe their copyright. Therefore conceptually this personal and civilian nature emphasizes the alignment of mindset that the complaint offence is more appropriately applied to copyright infringement. Whereas the relevance of complaint offence for protection and enforcement of copyright can be seen from the significant role of the creator or copyright holder in the law enforcement process. The creator or copyright holder can play an active role in providing information and evidence of copyright infringement so that the law enforcement process becomes more effective and efficient.
\end{abstract}

Keywords: ordinary offenses; complaint offenses; legal protection; law enforcement 


\begin{abstract}
Abstrak
Artikel ini membahas dua permasalahan pokok: pertama, apa urgensi perubahan delik biasa menjadi delik aduan dalam Undang-undang Hak Cipta; kedua, bagaimana relevansi perubahan sifat delik tersebut terhadap perlindungan dan penegakan hukum hak cipta. Urgensi perubahan delik biasa menjadi delik aduan adalah karena hak cipta merupakan hak eksklusif yang bersifat personal dan keperdataan. Sifat personal dan keperdataan ini mengindikasikan adanya hak mutlak dari pencipta atau pemegang hak cipta atas hasil karya ciptanya, termasuk hak untuk melaporkan atau tidak atas pelanggaran hak ciptanya. Oleh karena itu secara konseptual sifat personal dan keperdataan ini lebih mengedepankan keselarasan pola pikir bahwa delik aduan lebih tepat diterapkan terhadap pelanggaran hak cipta. Sedangkan relevansi delik aduan terhadap perlindungan dan penegakan hak cipta dapat dilihat dari peran yang signifikan dari pencipta atau pemegang hak cipta dalam proses penegakan hukum. Pencipta atau pemegang hak cipta dapat berperan aktif dalam memberikan keterangan dan bukti-bukti dari pelanggaran hak cipta tersebut sehingga proses penegakan hukum dapat berjalan lebih efektif dan efisien.
\end{abstract}

Kata Kunci: delik biasa; delik aduan; perlindungan hukum; penegakan hukum

\title{
A. Pendahuluan
}

Artikel ini membahas perubahan sifat delik dari delik biasa menjadi delik aduan dalam hukum hak cipta di Indonesia. Dalam undangundang yang berlaku saat ini, Undang-undang Nomor 28 Tahun 2014 tentang Hak Cipta, pelanggaran hak cipta dikategorikan sebagai delik aduan; sementara dalam undang-undang sebelumnya yaitu Undang-undang Nomor 19 Tahun 2002 tentang Hak Cipta, pelanggaran tersebut dikategorikan sebagai delik biasa. Dalam artikel ini, perubahan sifat delik tersebut akan dibahas urgensi dan relevansinya terhadap perlindungan dan penegakan hak cipta.

Hukum hak cipta di Indonesia sesungguhnya telah berlangsung sejak lama. Undang-undang Hak Cipta yang pertama kali berlaku adalah undang-undang warisan Belanda, Auteurwet 1912. Undangundang kolonial ini kemudian dicabut dengan Undang-undang No- 
mor 6 Tahun 1982 tentang Hak Cipta. Selanjutnya, Undang-undang Nomor 6 Tahun 1982 ini telah mengalami beberapa kali perubahan dalam kurun waktu dua dasawarsa. Perubahan pertama terjadi pada tahun 1987 dengan lahirnya Undang-undang Nomor 7 Tahun 1987 tentang Hak Cipta; perubahan kedua terjadi pada tahun 1997 melalui Undang-undang Nomor 12 Tahun 1997 tentang Perubahan atas Undang-undang Nomor 6 Tahun 1982 tentang Hak Cipta sebagaimana diubah dengan Undang-undang Nomor 7 Tahun 1987. Pada tahun 2002, Undang-undang Nomor 7 Tahun 1987 ini dicabut dan diganti dengan Undang-undang Nomor 19 Tahun 2002 tentang Hak Cipta. Pada akhirnya Undang-undang Nomor 19 Tahun 2002 inipun digantikan oleh Undang-undang Nomor 28 Tahun 2014 tentang Hak Cipta yang berlaku hingga saat ini.

Dalam rezim hak cipta, perubahan undang-undang tersebut diikuti pula dengan perubahan sifat delik dari delik aduan menjadi delik biasa, kemudian berubah lagi menjadi delik aduan. Rezim hak cipta pada masa Auteurwet 1912 hingga Undang-undang Nomor 6 Tahun 1982 masih menganut delik aduan. Dengan munculnya Undang-undang Nomor 7 Tahun 1987 dan Undang-undang Nomor 12 Tahun 1997 kemudian diikuti Undang-undang Nomor 19 Tahun 2002, terjadi perubahan sifat delik dari delik aduan menjadi delik biasa. Kemudian dengan Undang-undang Nomor 28 Tahun 2014 terjadi lagi perubahan dari delik biasa menjadi delik aduan.

Perubahan sifat delik itu menandakan adanya perkembangan delik hak cipta yang diikuti oleh perubahan paradigma berpikir pembentuk undang-undang. Pada waktu perubahan sifat delik yang pertama kali, yakni dengan dibentuknya Undang-undang Nomor 7 Tahun 1987, alasan perubahan adalah karena pelanggaran hak cipta pada saat itu sudah sampai pada tingkat yang mengkhawatirkan terutama terkait dengan pembajakan. Alasan lainnya adalah bahwa delik biasa dianggap sesuai dengan sifat utama dari hukum pidana, yaitu bahwa pelaksanaannya tidak digantungkan pada persetujuan atau pengaduan dari pihak yang dirugikan, melainkan diserahkan kepada aparat penegak hukum untuk menentukan apakah dan sampai di manakah hukum pidana akan dilaksanakan dengan menggunakan 
kepentingan publik sebagai ukuran.

Namun dalam penerapannya, delik biasa ini masih menyisakan berbagai permasalahan. Pertama, aparat penegak hukum kesulitan dalam mengungkap pelanggaran hak cipta tanpa melibatkan pencipta. Kedua, aparat penegak hukum tidak mengetahui secara persis, misalnya apakah seseorang telah mempunyai izin untuk mengumumkan atau memperbanyak suatu ciptaan. Ketiga, pihak yang dirugikan tidak punya pilihan untuk tidak menuntut pidana terhadap pelaku kalau kasus itu sudah diproses oleh aparat penegak hukum. Berangkat dari permasalahan tersebut, maka rezim Hak Cipta melalui Undang-undang Nomor 28 Tahun 2014 merubah sifat delik pelanggaran hak cipta dari delik biasa menjadi delik aduan. Persoalan yang dihadapi, yang kemudian menjadi ruang lingkup artikel ini, adalah apa urgensi perubahan sifat delik tersebut dan bagaimana relevansinya terhadap perlindungan dan penegakan hak cipta.

\section{B. Prinsip Dasar Hak Cipta dan Konsep Perlindungannya}

Hak Cipta adalah hak eksklusif pencipta yang timbul secara otomatis berdasarkan prinsip deklaratif setelah suatu ciptaan diwujudkan dalam bentuk nyata tanpa mengurangi pembatasan sesuai dengan ketentuan peraturan perundang-undangan. ${ }^{1}$ Maksud dari hak eksklusif atau hak khusus atas suatu ciptaan itu adalah tidak ada seorangpun yang boleh memanfaatkan hak tersebut tanpa seizin pencipta. Hak yang ada pada seseorang, termasuk hak cipta, mewajibkan orang lain untuk melakukan atau tidak melakukan suatu perbuatan. Dengan kata lain, semua orang mempunyai kewajiban untuk tidak merugikan orang lain dan pada saat yang bersamaan dia juga memiliki hak untuk tidak dirugikan.

Pasal 1 angka 3 Undang-Undang Nomor 28 Tahun 2014 menyebutkan bahwa ciptaan adalah hasil karya cipta di bidang ilmu pengetahuan, seni, dan sastra yang dihasilkan atas inspirasi, kemampuan pikiran, imajinasi, kecekatan, keterampilan, atau keahlian yang

1 Pasal 1 angka 1 Undang-undang Nomor 28 Tahun 2014 tentang Hak Cipta. 
diekspresikan dalam bentuk nyata. ${ }^{2}$ L.J Taylor sebagaimana dikutip Rachmadi Usman menyatakan bahwa yang dilindungi oleh hak cipta adalah ekspresi dari sebuah ide, bukan idenya itu sendiri. Artinya, yang dilindungi adalah sudah dalam bentuk nyata sebagai sebuah ciptaan, bukan masih dalam bentuk gagasan. ${ }^{3}$ Dari pengertian ini dapat dipahami bahwa ciptaan itu merupakan ekspresi atau hasil dari ide inspiratif yang telah dibentuk menjadi karya ciptaan, atau disebut juga ekspresi kreatif. ${ }^{4}$

Ruang lingkup hak cipta meliputi karya cipta dalam bidang ilmu pengetahuan, seni, dan sastra. Secara hakiki, hak cipta termasuk hak milik intelektual yang bersifat imaterial karena menyangkut ide, gagasan pemikiran, maupun imajinasi dari seseorang yang dituangkan dalam bentuk karya cipta, seperti buku ilmiah, karangan sastra, maupun karya seni. Hak cipta dalam konteks hak ekonomi juga dapat dikategorikan sebagai hak kebendaan karena dapat dipindahkan atau dialihkan. Beralih dan dialihkannya hak ekonomi tersebut, baik seluruhnya maupun sebagian, dapat dengan cara pewarisan, hibah, wakaf, wasiat, perjanjian tertulis, dijadikan milik negara, atau sebab lain yang dibenarkan sesuai dengan ketentuan peraturan perundangundangan. ${ }^{5}$

Perlindungan terhadap hak cipta berfungsi melindungi hak yang dimiliki oleh pencipta atas karya ciptaannya. Hak cipta juga melindungi potensi pencipta karena eksistensi terhadap kemampuan yang dimiliki untuk menciptakan suatu karya cipta. Perlindungan terhadap hak cipta pada dasarnya dimaksudkan sebagai upaya untuk mewujudkan iklim yang lebih baik bagi tumbuh dan berkembangnya gairah mencipta. Perlindugan terhadap hak cipta ini secara eksplisit

2 Pasal 1 angka 3 Undang-Undang Nomor 28 Tahun 2014 tentang Hak Cipta.

3 Rachmadi Usman, Hukum Hak atas Kekayaan Intelektual (Perlindungan dan Dimensi Hukumnya di Indonesia) (Bandung: Alumni, 2003), hlm. 121.

4 Mengenai obyek perlindungan hak cipta, juga bidang hak kekayaan intelektual lainnya, merupakan ekspresi kreatif, dapat dilihat dalam artikel M. Zulfa Aulia, "Perlindungan Ekspresi Kreatif Manusia: Telaah terhadap Perlindungan Hak Kekayaan Intelektual dan Ekspresi Budaya Tradisional”, Jurnal Hukum Ius Quia Iustum, 14, 3 (2007), hlm. 362-365.

5 Pasal 16 Undang-undang Nomor 28 Tahun 20014 tentang Hak Cipta. 
ditetapkan dalam Pasal 27 Deklarasi Universal Hak-hak Asasi Manusia yang berbunyi "Setiap orang mempunyai hak sebagai pencipta untuk mendapat perlindungan atas kepentingan-kepentingan moral dan materiel yang merupakan hasil dari ciptaannya di bidang ilmu pengetahuan, seni, dan sastra”. ${ }^{6}$

Pertanyaan yang muncul adalah mengapa diperlukan adanya perlindungan terhadap hak cipta seseorang? Beberapa dasar pembenar terhadap perlindungan hak cipta adalah berdasarkan reward theory, recovery theory, incentive theory, dan risk theory. Teori reward menjelaskan bahwa pencipta akan diberikan penghargaan atas usaha yang telah dilakukan seperti dalam bentuk pengakuan terhadap hasil karya intelektual. Teori recovery menjelaskan bahwa pencipta yang sudah mengeluarkan tenaga, waktu, dan biaya perlu diberikan kesempatan untuk memperoleh kembali apa yang sudah dihasilkannya. Teori incentive menjelaskan bahwa untuk mengembangkan kreativitas penemuan atau hasil karya intelektual seseorang, maka diperlukan sebuah insentif yang dapat memberikan motivasi sehingga kegiatan penelitian dapat berlanjut dan memberikan kemanfaatan. Sedangkan teori risk menjelaskan bahwa karya intelektual adalah hasil penelitian yang mengandung risiko sebagai upaya untuk menemukan atau memperbaiki dalam proses penelitian. ${ }^{7}$

Teori-teori tersebut mengisyaratkan bahwa di balik sistem perlindungan terhadap hak cipta ada serangkaian pemikiran bahwa pencipta telah mencurahkan pikiran, tenaga, dan dana untuk menciptakan sesuatu. Apabila ciptaannya digunakan oleh orang lain untuk tujuan komersial, maka pencipta mempunyai hak untuk memperoleh kompensasi atas penggunaan ciptaannya. ${ }^{8}$ Selaras dengan pernyataan tersebut, John Lock mengatakan bahwa hak atas kekayaan intelek-

6 Pasal 27 ayat (2) Deklarasi Universal Hak-hak Asasi Manusia: "Everyone has the right to the protection of the moral and material interests resulting from any scientific, literary or artistic production of which he is the author".

7 Sudaryat, dkk dalam Khoirul Hidayah, Hukum Hak Kekayaan Intelektual (Malang: Setara Press, 2017), hlm. 8. Lihat juga Bernard Nainggolan, Komentar Undang-undang Hak Cipta (Bandung: Alumni, 2016), hlm. 63.

8 Kholis Roisah, Konsep Hukum Hak Kekayaan Intelektual (HKI) (Malang: Setara Press, 2015), hlm. 28. 
tual yang timbul sebagai konsekuensi logis dari orang bekerja. Pencipta atau pemegang hak cipta sama seperti pekerja, mereka berhak mendapat imbalan atas karya ciptaannya. Dalam hal ini Lock mengkaitkan hak cipta dengan teori hukum alam, yang mana hukum alam memberi hak milik eksklusif atas suatu karya pencipta, memberi individu hak untuk mempertahankan dan hak untuk mengawasi karyakaryanya dan mendapatkan kompensasi yang adil atas sumbangan pemikirannya kepada masyarakat. ${ }^{9}$

Ruang lingkup perlindungan terhadap hak cipta meliputi hak ekonomi dan hak moral. Hak ekonomi adalah hak untuk memperoleh keuntungan ekonomi atas suatu ciptaan. Pencipta atau penemu mempunyai hak yang sifatnya eksklusif hanya untuk dirinya atau orang lain yang mendapatkan izin dari pencipta untuk bisa mengeksploitasi nilai ekonomi dari ciptaan tersebut. ${ }^{10}$ Hak ekonomi ini dapat dieksploitasi oleh pencipta atau dialihkan untuk dieksploitasi oleh pihak yang bertindak sebagai pemegang hak cipta. Ruang lingkup hak ekonomi pencipta meliputi penerbitan ciptaan, penggandaan ciptaan dalam segala bentuknya, penerjemahan ciptaan, pengadaptasian, pengaransemenan atau pentransformasian ciptaan, pendistribusian ciptaan atau salinannya, pertunjukan ciptaan, pengumuman ciptaan, komunikasi ciptaan, dan penyewaan ciptaan. ${ }^{11}$

Sedangkan hak moral adalah hak untuk mendapatkan perlindungan berupa pelekatan (right of attribution). Suatu karya cipta tidak boleh dipisahkan dari penciptanya. Oleh sebab itu pencipta harus senantiasa dilekatkan pada ciptaannya (doctrine of paternity). Suatu ciptaan juga tidak boleh diubah-ubah tanpa persetujuan penciptanya (doctrine of integrity). Jadi dalam hal ini terdapat dua macam hak moral, yaitu hak untuk diakui sebagai pencipta dan hak keutuhan karya

9 Hendra Tanu Atmadja, Hak Cipta-Musik atau Lagu (Jakarta: Universitas Indonesia Press, 2003), hlm. 19. Lihat juga Bernard Nainggolan, Pemberdayaan Hukum Hak Cipta dan Lembaga Manajemen Kolektif(Bandung: Alumni, 2011), hlm. 66.

10 Muhammad Djumhana dan Djubaedillah, Hak Milik Intelektual: Sejarah, Teori, dan Praktiknya di Indonesia (Bandung: PT Citra Aditya Bakti, 2014), hlm. 26.

11 Lihat Pasal 9 Undang-undang Nomor 28 Tahun 2014 tentang Hak Cipta. 
cipta. Hak yang pertama mempunyai maksud bahwa nama pencipta harus tercantum pada karya yang diperbanyak, diumumkan, atau dipamerkan di depan publik. Sedangkan hak yang kedua dimaksudkan untuk mencegah tindakan perubahan terhadap ciptaan yang berpotensi merusak atau merugikan reputasi pencipta. ${ }^{12}$

\section{Urgensi Perubahan Sifat Delik Hak Cipta}

Sebagaimana telah diuraikan di atas, Undang-undang Hak Cipta telah mengalami beberapa kali perubahan. Perubahan undang-undang tersebut diikuti pula perubahan sifat delik: dari delik aduan (Auteurrecht 1912 dan UUHC 1982) ke delik biasa (UUHC 1987, UUHC 1997, UUHC 2002), kemudian kembali lagi menjadi delik aduan (UUHC 2014). Dianutnya delik biasa itu cukup lama, yakni mulai tahun 1987 hingga tahun 2002. Namun dengan disahkannya Undang-undang Hak Cipta yang baru, yaitu Undang-undang Nomor 28 Tahun 2014, diadakan perubahan sifat delik dari delik biasa ke delik aduan.

Delik biasa (gewone delic) adalah delik yang dapat dituntut atau diproses tanpa dibutuhkan adanya pengaduan. Sedangkan delik aduan (klackt delic) adalah delik yang hanya dapat diproses apabila ada aduan dari pihak yang dirugikan. ${ }^{13}$ Perkara yang termasuk dalam kategori delik biasa tidak dapat dihentikan meskipun para pihak telah memutuskan untuk berdamai. Dengan dianutnya delik aduan oleh Undang-undang Nomor 28 Tahun 2014, aparat penegak hukum tidak lagi dapat berperan aktif dalam menaggulangi pelanggaran hak cipta tanpa ada aduan dari pihak pencipta atau pemegang hak cipta yang merasa dirugikan.

12 Khoirul Hidayah, Hukum Hak Kekayaan Intelektual, hlm. 8. Lihat juga Agus Sardjono, "Hak Cipta Bukan Hanya Copyright", Jurnal Hukum dan Pembangunan, 40, 2 (2010), hlm. 254. Dalam buku Henry Soelistyo (Hak Cipta Tanpa Hak Moral [Jakarta: Rajawali Pers, 2011], hlm. 105-112) disebutkan ada satu hak lagi di luar hak atribusi (atribution right) dan hak integritas (right of integrity), yaitu hak keterkaitan atau asosiasi dengan pencipta. Namun hak yang disebut terakhir ini pada dasarnya merupakan bagian dari hak integritas pencipta.

13 Eddy O.S. Hieriej, Prinsip-Prinsip Hukum Pidana (Yogyakarta: Cahaya Atma Pustaka, 2014), hlm. 110. Lihat juga P.A.F. Lamintang dan Simons, Kitab Pelajaran Hukum Pidana (Bandung: Pionir Jaya), hlm. 145. 
Perubahan delik biasa menjadi delik aduan dalam rezim hak cipta bertujuan untuk semakin menegaskan bahwa hak cipta adalah hak yang bersifat personal (personal rights). Karena hak cipta adalah bersifat personal, apabila terjadi pelanggaran maka diperlukan adanya pengaduan dari pihak pencipta yang merasa dirugikan atas pelanggaran tersebut. Dengan delik aduan maka akan jelas siapa pencipta atau pemegang hak cipta dari karya yang disalahgunakan. Jadi perubahan sifat delik dari delik biasa menjadi delik aduan dikarenakan terkait dengan sifat kepemilikan itu sendiri. Artinya kepemilikan dalam hak cipta bersifat personal sehingga reasoning-nya adalah, pribadi yang merasa dirugikan itulah yang akan mengadu kepada pihak berwajib supaya kasusnya diusut. ${ }^{14}$

Perubahan delik biasa menjadi delik aduan dalam rezim hak cipta juga dilandasi oleh pemikiran bahwa hak cipta adalah hak keperdataan. Sebagai hak keperdataan, pencipta mempunyai hak mutlak untuk mempertahankan hak cipta atas benda ciptaannya ataukah tidak. Pencipta memiliki hak untuk mengizinkan atau melarang pihak lain untuk menggunakan hak ciptanya sehingga terserah kepada pencipta pula hendak mengambil tindakan seperti apa terhadap pihakpihak yang dianggap melanggar haknya tersebut, apakah melapor ke aparat penegak hukum sebagai perkara pidana ataukah perkara perdata melalui prosedur tuntutan ganti kerugian. ${ }^{15}$ Pertimbangan untuk melakukan atau tidak melakukan penuntutan sepenuhnya diserahkan kepada pencipta atau pemegang hak cipta itu sendiri. Oleh karena itu, secara konseptual delik aduan lebih mengedepankan keselarasan pola pikir bahwa hak cipta merupakan hak keperdataan. ${ }^{16}$

Dalam tataran praktis, paling tidak ada tiga alasan mengapa

14 Hasil Rapat Panitia Kerja (Panja) Rancangan Undang- Undang Hak Cipta dengan Agung Damarsasongko, Kepala Seksi Pertimbangan Hukum dan Litigasi Direktorat Hak Cipta, Desain Industri, DTLST, dan Rahasia Dagang, tanggal 26 Agustus 2014. Lihat juga Trias Palupi Kurnianingrum, "Materi Baru dalam Undang-undang Nomor 28 Tahun 2014 tentang Hak Cipta”, Negara Hukum, 6, 1 (2015), hlm. 100.

15 Trias Palupi Kurnianingrum, "Materi Baru dalam Undang”, hlm. 100.

16 O.K Saidin, Aspek Hukum Hak Kekayaan Intelektual (Intellectual Property Rights) (Jakarta: Rajawali Pers, 2010), hlm. 48. 
delik aduan dalam rezim hak cipta dianggap cukup tepat. Pertama, dalam melakukan proses hukum, aparat penegak hukum sulit menentukan apakah telah terjadi pelanggaran hak cipta tanpa membandingkan barang hasil pelanggaran dengan ciptaan aslinya yang dipegang oleh pencipta atau pemegang hak cipta. Oleh karena itu aparat penegak hukum dirasa sulit untuk melakukan tindakan tanpa adanya pengaduan terlebih dahulu dari pencipta atau pemegang hak cipta yang merasa dirugikan atas pelanggaran tersebut. Kedua, dalam melakukan proses hukum, aparat penegak hukum kesulitan untuk mengetahui apakah suatu pihak telah mendapat izin untuk mengumumkan atau memperbanyak suatu ciptaan tanpa ada pengaduan terlebih dahulu dari pencipta atau pemegang hak cipta. Ketiga, apabila kasus pelanggaran hak cipta sudah diproses oleh aparat penegak hukum, maka tertutup kemungkinan bagi pencipta atau pemegang hak cipta untuk memilih penyelesaian di luar pengadilan, misalnya ganti kerugian ataupun dengan perdamaian. ${ }^{17}$

Beberapa negara ASEAN juga menerapkan delik aduan terhadap pelanggaran hak cipta. Malaysia dengan Copyright Act 1987 dan Thailand dalam Copyrightright Act be 2537 adalah dua negara yang dapat dijadikan sebagai perbandingan. Padahal dalam era Masyarakat Ekonomi Asean (MEA), karya-karya asing dengan mudah masuk ke negara anggota MEA. Apabila Indonesia tetap mempertahankan menggunakan delik biasa, maka kepentingan orang asing di Indonesia sangat terlindungi. Hal ini disebabkan karena apabila karya warga negara asing disalahgunakan di Indonesia, warga negara asing tidak perlu datang ke Indonesia untuk melapor. Aparat penegak hukum mempunyai kewenangan untuk menindak setiap ada pelanggaran hak cipta walaupun tidak ada laporan dari pihak yang dirugikan. Sebaliknya, kepentingan warga negara Indonesia sendiri di negara lain tidak terlindungi secara maksimal karena negara-negara tersebut menggunakan delik aduan yang tidak serta merta aparat penegak hukum dapat melakukan tindakan tanpa ada aduan dari pihak yang

17 Ari Juliano Gema, “Tindak Pidana Hak Cipta: Lebih Baik Delik Biasa atau Delik Aduan”, http://arijuliano.blogspot.com/2008/02/tindak-pidanahak-cipta-lebih-baik.html, diakses 15/1/2019. 
dirugikan. ${ }^{18}$

Faktor lain yang menjadi dasar pertimbangan kebijakan legislatif terhadap perubahan sifat delik hak cipta menjadi delik aduan itu terkait dengan Indonesia sebagai negara peserta yang telah meratifikasi World Trade Organization (WTO) yang memberlakukan TRIPs Agreement sebagai sumber hukum yang di dalamnya terdapat ketetapan bahwa hak kekayaan intelektual adalah hak privat (privat right). ${ }^{19}$ Sebagai konsekuensi, maka Indonesia terikat dengan segala ketentuan TRIPs Agreement termasuk pada ketentuan hak kekayaan intelektual yang merupakan hak keperdataan yang bersifat ekslusif, sehingga delik aduan dirasa lebih tepat untuk diterapkan dalam proses pidana terhadap pelanggaran hak cipta. ${ }^{20}$

\section{Relevansi Perubahan Sifat Delik terhadap Perlindungan dan Penegakan Hak Cipta}

Hak Cipta sebagai hak eksklusif mempunyai kedudukan yang tinggi sehingga tidak ada pihak lain yang dibenarkan untuk memanfaatkan hak tersebut tanpa ada izin dari pencipta atau pemegang hak cipta. Pencipta maupun pemegang hak cipta dapat menempuh upaya hukum baik secara perdata dengan mengajukan gugatan ke Pengadilan Niaga atau melaporkan dugaan pelanggaran tersebut ke pihak yang berwajib. Jadi pada hakikatnya pelanggaran hak cipta bukan saja memiliki konsekuensi hukum secara pidana namun juga dapat dimintakan ganti rugi secara perdata.

Terobosan baru terhadap perlindungan hak cipta oleh Undangundang Nomor 28 Tahun 2014 adalah melalui alternatif penyelesaian sengketa, arbitrase, atau pengadilan. ${ }^{21}$ Di dalam ketentuan ini ditegaskan bahwa apabila terjadi sengketa hak cipta maka diharus-

18 Ari Juliano Gema, “Tindak Pidana Hak Cipta”.

19 Achmad Zen Umar Purba, Perjanjian dan Beberapa Isu Strategis (Bandung:Alumni, cetakan kedua, 2016), hlm. 16

20 Naskah Akademik Rancangan Undang-Undang Tentang Hak Cipta 2013, hlm. 25.

21 Pasal 95 ayat (1) Undang-undang Nomor 28 Tahun 2014 tentang Hak Cipta: "Penyelesaian sengketa hak cipta dapat dilakukan melalui alternatif penyelesaian sengketa, arbitrase, atau pengadilan" 
kan menempuh terlebih dahulu penyelesaian sengketa melalui mediasi sebelum melakukan tuntutan pidana. Demikian juga halnya terhadap penyelesaian sengketa hak cipta yang salah satu pihaknya berada di luar negeri, diakomodasi ketentuan penyelesaian melalui mediasi sebelum melakukan tuntutan pidana. ${ }^{22}$

Selain itu setiap pencipta, pemegang hak cipta, dan pemilik hak terkait juga bisa mengajukan gugatan ganti rugi melalui Pengadilan Niaga atas pelanggaran hak cipta atau produk terkait. Gugatan ganti rugi sebagaimana dimaksud dapat berupa permintaan untuk menyerahkan seluruh atau sebagian penghasilan yang diperoleh dari penyelenggaraan ceramah, pertemuan ilmiah, pertunjukan, atau pameran karya yang merupakan hasil pelanggaran hak cipta atau produk hak terkait. Selain itu, pencipta, pemilik hak cipta dan pemegang hak terkait juga bisa mengajukan putusan sela kepada Pengadilan Niaga. Putusan sela dimintakan ke Pengadilan Niaga untuk: meminta penyitaan ciptaan yang dilakukan pengumuman atau penggandaan, dan/atau alat penggandaan yang digunakan untuk menghasilkan ciptaan hasil pelanggaran hak cipta dan produk hak terkait; dan/atau menghentikan kegiatan pengumuman, pendistribusian, komunikasi atau penggandaan ciptaan yang merupakan hasil pelanggaran hak cipta dan produk hak terkait. ${ }^{23}$

Selain disebutkan tentang penyelesaian sengketa melalui alternatif penyelesaian sengketa dan arbritase, pencipta, pemegang hak cipta dan pemilik hak terkait yang merasa dirugikan juga bisa meminta Penetapan Sementara Pengadilan. Pengadilan Niaga dapat mengeluarkan penetapan sementara untuk: mencegah masuknya barang yang diduga hasil pelanggaran hak cipta atau hak terkait ke jalur perdagangan; menarik dari peredaran dan menyita serta menyimpan

22 Pasal 95 ayat (4) Undang-undang Nomor 28 Tahun 2014 tentang Hak Cipta: "Selain pelanggaran Hak Cipta dan/atau Hak Terkait dalam bentuk Pembajakan, sepanjang para pihak yang bersengketa diketahui keberadaannya dan/atau berada di wilayah Negara Kesatuan Republik Indonesia harus menempuh terlebih dahulu penyelesaian sengketa melalui mediasi sebelum melakukan tuntutan pidana".

23 Lihat Pasal 99 ayat (2) dan (3) Undang-undang Nomor 28 Tahun 2014 tentang Hak Cipta. 
sebagai alat bukti yang berkaitan dengan pelanggaran hak cipta atau hak terkait tersebut; mengamankan barang bukti dan mencegah penghilangannya oleh pelanggar; dan/atau menghentikan pelanggaran guna mencegah kerugian yang lebih besar. ${ }^{24}$

Sebagai tambahan, berdasarkan Pasal 105 Undang-undang Hak Cipta disebutkan bahwa "hak untuk mengajukan gugatan keperdataan atas pelanggaran hak cipta dan/atau hak terkait tidak mengurangi hak pencipta dan/atau pemilik hak terkait untuk menuntut secara pidana”. Ketentuan pidana dalam Undang-undang Hak Cipta pada dasarnya berfungsi sebagai ultimum remedium, dalam arti bahwa hukum pidana dijadikan upaya terakhir dalam hal penegakan hukum. ${ }^{25} \mathrm{Hal}$ ini memiliki makna apabila suatu perkara dapat diselesaikan melalui jalur lain (kekeluargaan, negosiasi, mediasi, perdata, ataupun hukum administrasi) hendaklah jalur tersebut ditempuh terlebih dahulu. Setelah upaya penyelesaian di luar pengadilan melalui negosiasi, mediasi, ataupun tuntutan ganti kerugian melalui pengadilan perdata, maka sebagai upaya terakhir, pihak yang dirugikan dapat menempuh jalur pidana.

Mendasarkan pada uraian tersebut di atas, maka dapat dikatakan bahwa Undang-undang Nomor 28 Tahun 2014 tentang Hak Cipta lebih secara rinci dan detail memberikan perlindungan hukum baik secara perdata maupun pidana terhadap pencipta, pemilik hak cipta, maupun pemilik hak terkait. Dapat dikatakan juga bahwa undang-undang ini telah lebih baik dibandingkan undang-undang sebelumnya, karena memberikan ruang untuk menyelesaikan sengketa dengan jalur penyelesaian sengketa secara efektif di luar pengadilan. Dengan demikian pada garis besarnya perlindungan hukum terhadap hak cipta bukan saja merupakan pengakuan negara terhadap karya cipta seorang pencipta, tetapi juga diharapkan bahwa perlindungan tersebut akan dapat membangkitkan semangat dan minat yang lebih

24 Lihat Pasal 106 Undang-undang Nomor 28 Tahun 2014 tentang Hak Cipta.

25 Jan Remmelink, Hukum Pidana: Komentar atas Pasal-pasal Terpenting dari Kitab Undang-undang Hukum Pidana Belanda dan Padanannya dalam Kitab Undang-undang Hukum Pidana Indonesia (Jakarta: Gramedia Pustaka Utama, 2003), hlm. 14-15. 
besar untuk melahirkan ciptaan baru di bidang tersebut. Prinsip dalam pemberian perlindungan hak cipta yang dianut dalam undangundang ialah pemberian perlindungan kepada semua ciptaan warga negara Indonesia dengan tidak memandang tempat di mana ciptaan diumumkan untuk pertama kali. ${ }^{26}$

\section{E. Kesimpulan}

Berdasarkan analisis dan pembahasan di atas, artikel ini menyimpulkan ada beberapa faktor yang dapat diidentifikasi terkait urgensi diterapkannya delik aduan dalam pelanggaran hak cipta. Pertama, hak cipta adalah hak yang bersifat personal dan merupakan hak keperdataan yang bersifat eksklusif. Kedua, delik aduan bertujuan untuk memperjelas siapa pencipta atau pemegang hak cipta atas karya yang disalahgunakan. Ketiga, TRIP’s Agreement dengan tegas menyatakan bahwa hak kekayaan intelektual termasuk hak cipta adalah private rights sehingga menjadi relevan terhadap aturan pidana yaitu delik aduan. Keempat, negara-negara di ASEAN juga menganut delik aduan dalam undang-undang hak ciptanya. Indonesia seyogianya menyesuaikan diri sehingga terdapat sinergitas yang baik dalam melakukan kerjasama penegakan hukum di bidang hak cipta dengan negara-negara tersebut.

Artikel ini juga menyimpulkan, perlindungan dan penegakan hukum terhadap pencipta atau pemegang hak cipta akan lebih efektif dan efisien apabila menggunakan delik aduan ketimbang delik biasa. Delik biasa yang digunakan dalam Undang-undang Hak Cipta yang lama pada kenyataannya mempersulit aparat penegak hukum dalam mencari alat bukti guna proses penyidikan dan pembuktian di pengadilan. Dengan delik aduan pada undang-undang yang baru diharapkan akan lebih mempermudah dan mempercepat proses penegakan hukum karena aparat penegak hukum tidak akan kesulitan dalam mencari barang bukti dan untuk membandingkan antara barang bukti yang asli dengan barang bukti hasil pelanggaran. Alat bukti

26 Mirwansyah, "Analisis Hukum terhadap Tindak Pidana Hak Cipta (Ditinjau dari Undang-undang Nomor 28 Tahun 2014 tentang Hak Cipta)", https: / / osf.io/56kbn $/$. 
yang diperlukan tersebut telah disiapkan oleh pencipta atau pemegang hak cipta sebagai pihak yang mengadukan adanya pelanggaran hak cipta tersebut.

\section{Daftar Pustaka}

\section{Artikel/Buku/Laporan}

Atmadja, Hendra Tanu. Hak Cipta-Musik atau Lagu. Jakarta: Universitas Indonesia Press, 2003.

Aulia, M. Zulfa. "Perlindungan Ekspresi Kreatif Manusia: Telaah terhadap Perlindungan Hak Kekayaan Intelektual dan Ekspresi Budaya Tradisional”. Jurnal Hukum Ius Quia Iustum, 14, 3 (2007): 359-372.

Djumhana, Muhammad dan Djubaedillah. Hak Milik Intelektual: Sejarah, Teori, dan Praktiknya di Indonesia. Bandung: PT Citra Aditya Bakti, 2014.

Hasil Rapat Panitia Kerja (Panja) Rancangan Undang-Undang Hak Cipta dengan Agung Damarsasongko Kepala Seksi Pertimbangan Hukum dan Litigasi Direktorat Hak Cipta, Desain Industri, DTLST, dan Rahasia Dagang, 26/8/2014.

Hidayah, Khoirul. Hukum Hak Kekayaan Intelektual. Malang: Setara Press, 2017.

Hieriej, Eddy O.S. Prinsip-Prinsip Hukum Pidana. Yogyakarta: Cahaya Atma Pustaka. 2014.

Http:/ / m.hukumonline.com. "Hindari Polisi Nakal, RUU Hak Cipta Gunakan Delik Aduan”, 4/6/2014. Diakses 12/11/2015.

Kurnianingrum, Trias Palupi. "Materi Baru dalam Undang-undang Nomor 28 Tahun 2014 tentang Hak Cipta”. Negara Hukum, 6, 1 (2015): 93-106. DOI: 10.22212/jnh.v6i1.249

Lamintang, P.A.F. dan Simons. Kitab Pelajaran Hukum Pidana. Bandung: Pionir Jaya, 1981.

Mirwansyah. "Analisis Hukum terhadap Tindak Pidana Hak Cipta Ditinjau dari Undang-undang Nomor 28 Tahun 2014 tentang Hak Cipta”. https://osf.io/56kbn/. DOI: 10.17605/OSF. $\mathrm{IO} / 56 \mathrm{KBN}$ 
Nainggolan, Bernard. Pemberdayaan Hukum Hak Cipta dan Lembaga Manajemen Kolektif. Bandung: Alumni, 2011.

Nainggolan, Bernard. Komentar Undang-undang Hak Cipta. Bandung: Alumni, 2016.

Purba, Achmad Zen Umar. Perjanjian dan Beberapa Isu Strategis. Bandung: Alumni, cetakan kedua, 2016.

Remmelink, Jan. Hukum Pidana: Komentar Atas Pasal-pasal Terpenting dari Kitab Undang-undang Hukum Pidana Belanda dan Padanannya dalam Kitab Undang-undang Hukum Pidana Indonesia. Jakarta: Gramedia Pustaka Utama, 2003.

Republik Indonesia. Naskah Akademik Rancangan Undang-Undang tentang Hak Cipta 2013.

Roisah, Kholis. Konsep Hukum Hak Kekayaan Intelektual (HKI). Malang: Setara Press, 2015.

Saidin, O.K. Aspek Hukum Hak Kekayaan Intelektual (Intellectual Property Rights). Jakarta: Rajawali Pers, 2010.

Sardjono, Agus. "Hak Cipta Bukan Hanya Copyright". Jurnal Hukum dan Pembangunan, 40, 2 (2010): 252-269. DOI: 10.21143/jhp. vol40.no2.217

Soelistyo, Henry. Hak Cipta Tanpa Hak Moral. Jakarta: Rajawali Pers, 2011.

Usman, Rachmadi. Hukum Hak atas Kekayaan Intelektual (Perlindungan dan Dimensi Hukumnya di Indonesia). Bandung: Alumni, 2003.

\section{Peraturan Hukum}

Republik Indonesia. Undang-undang Nomor 28 Tahun 2014 tentang Hak Cipta.

United Nations. Universal Declaration of Human Rights (1948). 